\title{
SOCIAL PHILOSOPHICAL CHARACTERISTICS OF SPEAKING SKILLS
}

\author{
Irodakhon Shokhitbekovna Akhmedova \\ Basic doctorate of Andizhan State University, \\ Republic of Uzbekistan
}

Article DOI: https://doi.org/10.36713/epra4871

\begin{abstract}
The article analyzes the social philosophical properties of speech skills using the scientific literature and also communication culture among young people, especially in public speaking skills and abilities as well. Therefore, the study of the history, socio-philosophical nature, essence, characteristics, history of origin, development factors, its role in the process of spiritual enlightenment and ways to improve the oratory skills of spiritual preachers has become a special scientific and practical need.
\end{abstract}

KEY WORDS: oratory, spirituality, enlightenment, Discovery, communication, speech culture, Babur, Renaissance, word, sermon, preaching, Orientation, eloquence.

\section{INTRODUCTION}

In Uzbekistan, which is developing from "national revival to national uplift", ample opportunities are being created for everyone to express themselves. At the same time, there is a lack of communication culture among young people, especially in public speaking skills and abilities. This increases the demand for individuals who are able to perform current socio-political tasks, have a socially active, lively and lively speech culture, have mastered the basics of public speaking have a culture of communication, negotiation, debate. The democratic society the rule of law, pluralism, openness, stereotypes, indifference and dry propaganda are being abandoned in our country. Spirituality and enlightenment are the priorities of the state policy of the Republic of Uzbekistan, and oratory is the main tool for the implementation of this policy. Therefore, the study of the history, sociophilosophical nature, essence, characteristics, history of origin, development factors, its role in the process of spiritual enlightenment and ways to improve the oratory skills of spiritual preachers has become a special scientific and practical need.

\section{METHODS}

The works of our great thinkers and historical sources play an important role in studying the role of public speaking skills in the development of spiritual and moral thinking in society. In this regard, the views of such commanders and thinkers as Hussein Waiz Kashifi, "Nightmare", Imam Bukhari, Abu Nasr Farobi, Amir Temur, Abulqasim Zamahshari, Ahmad Yassavi, Alisher Navoi, Zahiriddin Muhammad Babur serve as an important historical source. From time immemorial, in the spiritual and enlightenment life of the East, the art of oratory has been considered as an important tool for the stability of public life.

\section{RESULTS AND DISCUSSIONS}

An example of this is the conclusion in the Nightmare, "The best of all human abilities is the ability to speak" [1]. History has many examples that prove that the great orator, the preachers 'appeals served to mobilize the people, performing powerful spiritual unifying functions even in times of peace and war. A study of historical sources shows that in the upbringing of princes, special attention was paid to teaching them eloquence. For example, Mir Alisher Navoi described Sultan Hussein Boykaro's eloquence in his Majlis un-nafais: [2]. As can be seen, among the many qualities of Hussein Boykaro, his oratory skills are especially recognized. Fakhriddin Ali Safi, the son of Husayn Waiz Kashifi, in his work Latoif ut-tawaif, left rich sources about his father's activities, including oratory. "One day" writes Fakhriddin Ali Safi, "the famous master of speech, Mawlana Sayyid Ghiyasiddin, came to the meeting much later". Abdurahman Jami was also 
present at the meeting. When Sayyid Ghiyasiddin entered, Jami asked him: "How late are you, Mavlono Giyasiddin?" "Excuse me, Master," said Giyosiddin, "I was on my way, and I fell in love with Hussein Waiz while he was giving a speech in the mosque". Apparently, Hussein Waiz Kashifi's speeches were able to attract anyone with their charm. Of course, the famous preacher Hussein Waiz Kashifi was very famous for his art of preaching. An example of this is a historical event. It is known that on November 8, 1492, the great poet Abdurahman Jami died. At the funeral, Alisher Navoi commissioned Hussein Waiz Kashifi to recite his lament. It is clear that reading the text in a beautiful, fluent, understandable way is also a manifestation of oral culture. At the same time, expressive reading of poetic and prose works, memorization, polishing of words increased the effectiveness of the preacher's speech. The art of public speaking served as a powerful spiritual factor not only in peacetime, but also in times of war, war, and war. As noted above, princes and future commanders were taught the art of public speaking. The king and commander-in-chief inspected his soldiers before the battle and addressed them. This had an ideological impact on the army and inspired the warriors. Later, a special preaching service was established under kings and emirs. For example, Mawlana Nizamiddin Shami, who entered the service of Amir Temur in 1393, also served as a preacher in the military campaigns of Sahibkiran until 1404, preaching sermons to commanders before entering major battles.

Another historical example. Zahiriddin Muhammad Babur gave a speech in front of his army before the battle against the troops of Ibrahim Lodi near Pinipat on the Indian march. His army numbered only 12,000 , including women and the elderly. This army was facing an army of 100,000 men, including war elephants, in front of Abraham Ludi. In his prewar sermon, Babur said that they were strangers and wanderers in this country, and that, God forbid, if they were defeated, they would have nowhere to go and no place to flee. He emphasizes that this battle is a battle of life and death, emphasizes that if they win, they will be martyrs, and if they die, they will be martyred. As a result, his army of 12,000 men will defeat the enemy of 100,000 men. Abdullah Avloni, in his book "Turkish Gulistan or Morality", describes the etiquette of speech as follows: "A word is a balance that measures a person's level and perfection, knowledge and phase. The wise know the thoughts and intentions of the heart, the knowledge and power, the dignity and worth of what one speaks" [3]. Avloni says that a fool is deprived of thought, observation, and is spiritually poor. Hence, science emphasizes that those who have attained eloquence and maturity are extremely intelligent while being skilled orators. Abdullah Qadiri, a well-known writer and speaker on the culture of speech, said: "When the word is left and the thought is ripe from the jar in it, let it be the basis for a new awning of life! It takes a long time to speak and compose sentences from them" [4], and he also gave a deep meaning to the speech of the characters of his works. As we read his works, we feel the writer's high speaking skills through the speeches of Yusufbek Haji, Otabek, Anvar Mirzo. In the XIX century in Bukhara, Kokand, Khiva khanates, Khorasan and Iran many preachers and masters of speech appeared. An example of this can be seen in the poem "Travelogue" by the poet Muhammad Aminkhoja Muqimi, who lived in Kokand in the XIX century. The poet says that a sermon is being preached in Ultarma, one of the villages of the Ferghana Valley:

I saw a whole campaign,

Another night covered with a blanket,

I see five hundred women

The preacher listens [5].

\section{CONCLUSION}

In short, the development of the First and Second Renaissances in our country was given invaluable spiritual power by the art of preaching in the East, the activities of preachers, methods of propaganda. Along with such scholars as Alisher Navoi, Kaykovus, Abu Nasr Farobi, Mahmud Zamahshari, Abu Rayhan Beruni, Ahmad Yugnaki, Mahmud Kashgari, Abdullah Avloni, almost all our scholars, writers and poets in their writings have focused on the value of words, attention to language and speech skills. It is true that a person who speaks beautifully, eloquently and meaningfully does not become a preacher. This art has its own principles and rules, the knowledge and application of which serve to mobilize the spiritual and enlightenment officials to build the foundations of the Third Renaissance by improving their public speaking skills.

\section{REFERENCES}

\footnotetext{
1. Kaykovus. Kabusnoma .-Tashkent: Ukituvchi, 2011. - 81 p.

2. Navoi Alisher. A perfect collection of works. 20 volumes. Volume 13 Assembly un-nafois. Tashkent: Fan, 1997, p.173.

3. Abdulla Avloni. Turkiy Guliston yokhud akhlok. Tashkent: Ukituvchi, 1992, p.266.

4. The homeland and the nation are sacred. Tashkent: Ma'naviyat, 2000, p.67.

5. Uzbek literature. Complex. Volume 4, Book I, T., State Publishing House of Fiction, 1960.
} 